\title{
TRADITION AND INNOVATION
} IN THE BANDURA PERFORMANCES OF VASYL YEMETZ

\author{
Victor Mishalow
}

PhD in Arts, Adjunct Research Fellow; ORCID: 0000-0002-5194-8964; e-mail: victor.mishalow@yahoo.com Monash University, Melbourne, Australia

\begin{abstract}
In the XX century, specific individuals in the Ukrainian Diaspora preserved, developed and propagated aspects of bandura culture and tradition, much of which disappeared in Ukraine in the light of new political realities. This included such aspects as the loss of the Kharkiv type bandura, the Kharkiv method and technique of playing, and its traditional repertoire. During the 20th century, Vasyl Yemetz made a significant contribution to the development of the modern bandura and the establishment of the solo concert performance on the instrument. This study is an attempt to glean new information regarding traditional playing techniques he learned as a youth and new techniques he later developed, and also a reevaluation of his repertoire based on reminiscences and recordings made by the author in 1979.
\end{abstract}

The purpose of this research is to focus on traditional, transformational and innovational aspects in the performance practice and playing technique of Vasyl Yemetz; to reevaluate those aspects of the kobzar tradition that he retained, and those that he modified in his concert performance practices, and to compare these to contemporary practices later developed in Ukraine.

The research methodology is grounded in historic, systemic, sociological and cultural approach and related methods of scientific study, in particular, a historic-chronological analysis of the bandura playing techniques used by Vasyl Yemetz, in particular, the method of systematic classification and complex analysis of the playing techniques that he retained and also later developed. The study and analysis are directed toward the bandura playing technique and repertoire of Vasyl Yemetz and his philosophy regarding his approach to the bandura.

The materials used in the preparation of this study include books and articles regarding the bandura, and specifically about Vasyl Yemetz, recordings on cassette tape and photographs made by the author. Separate conclusions and generalizations were made on the basis of personal interaction with the informant and also notes taken at that time.

The scientific novelty of the research is the introduction into scientific circulation of an organological and ergological analysis of the activities of bandurist Vasyl Yemetz, the tradition, systematization of the various adaptations, and the development of independent innovations in the performance practice by this artist on this traditional Ukrainian folk instrument.

Conclusions. Vasyl Yemetz was a unique man and musician. He made a significant impact on the development of bandura playing technique, repertoire and instrument construction. The artist combined in his work a traditional kobzar playing and innovations of modern concert performance. 
Audio recordings and photographic materials made during personal meetings contributed to the rethinking of his artistic, philosophical, cultural achievements, especially in the aspects of playing techniques and the formation of concert repertoire.

Musical terms developed and implemented by the performer to describe playing techniques can still be used nowadays in the technique of bandura playing. The audio recordings of the melodies made during the interview contributed to reconstruct his repertoire and to involve these works actively in the concert repertoire of modern bandura players.

The interrelation of technical performing techniques and design features of the instrument, which explains the motives of the philosophical understanding of the bandura art role in the world cultural process, is highlighted.

Keywords: bandura; kobzar; Vasyl Yemetz; playing technique; Ukrainian Diaspora

\section{Introduction}

In 1978, the writer received a scholarship from the Australia Council of the Arts to improve his technical playing skills studying under prominent bandura players living who resided in North America.

In December 1987, he flew from Sydney to North America where he had the opportunity to study with the prominent bandura players of the Ukrainian Bandurist Chorus in Detroit: Peter Kytasty and Peter Honcharenko. In Detroit he consulted with bandurists Mykola Liskivsky, Hryhoriy Nazarenko (a participant of the Poltava Bandurist Capella from 1925) and later with the artistic director of the Ukrainian Bandurist Chorus - Hryhory Kytasty. Being in North America, he also had the opportunity to spend time with the artistic director of NY School of Bandura, Serhiy Kindzeryav-Pastikhiv (a student of bandurist K. Misevych) and R. Levitsky, and also communicated with Z. Shtokalko's close friend - Levko Maistrenko. In Toronto, he met up with the director of the bandura ensembles, Mrs. Valentina Rodak, as well as with Myroslav Diakovsky (a student of Z. Shtokalko), and in Winnipeg with the kobza player Pavlo Konoplenko-Zaporozhetz.

On his way home to Australia, he visited Los Angeles, where he had the opportunity to spend time with Vasyl Yemetz, a virtuoso bandurist and the founder of the first professional bandura ensemble organized in Kyiv in 1918, which grew into the Kyiv State Bandurist Capella.

Previously, the writer had corresponded with Mr. Yemetz, raising numerous questions about bandura playing techniques and other aspects regarding the history of the bandura.

The writer flew to Los Angeles and traveled by bus to Hollywood where he stayed with Yemetz for a period of 7 days.

We spoke for a short time and after a small meal was invited to demonstrate my playing. After playing, I looked over his instruments, tuned them up and played them. I looked over his archives and we continued to talk at length recording some of the conversations on a cassette recorder.

\section{Purpose of the researh}

The goal of this study is to focus on traditional, transformational and innovational aspects in the performance practice and playing technique of Vasyl Yemetz; to reevaluate those aspects of the kobzar tradition that he retained, and those that he modified in his 
concert performance practices, and to compare these to contemporary practices later developed in Ukraine.

\section{Recent research and publications analysis}

A scientific analysis of the activities of this renowned bandura player has not been yet undertaken. The proposed article is an initial attempt to understand the scale of activities undertaken by V. Yemetz, although some features of his creative work are touched on in the works of V. Dutchak. Comparative characterization of traditional and innovative features in V. Yemets' work is carried out on the basis of organological and ergological analysis of his artistic performance activity observed in personal interaction.

\section{Presentation of the main material}

The official biography of Vasyl Yemetz is readily available and has appeared in various publications and is also available on the Internet. It was reprinted several times. Yemetz (1961) also had a large memorial bibliographical book published in 1961 where important articles, reviews and photographs were collected. Unfortunately, in more recent years few bandurists or musicologists had communicated with him, much less had the opportunity to talk to him in depth about the bandura, the traditional kobzars or about the state of Ukrainian music in the early 20th century. Yemetz was the single concert bandura player who had studied directly from the traditional blind kobzars. He was also very closely connected with the first stage performing bandura players - a phenomenon that developed in the early 20th century (Dutchak, 2011).

Vasyl Yemetz personally knew such prominent traditional kobzars from the Kharkiv region such as I. Kucherenko. P. Drevchenko, P. Hashchenko, H. Honcharenko and also met up with the kobzars from other regions such as Chernihiv kobzar T. Parkhomenko and Poltava kobzar M. Kravchenko. He knew many prominent bandura players in major cities such as Moscow, Kyiv, Katerynodar in the Kuban and Prague. His sister married a member of the Kyiv Bandurist Capella ( $\mathrm{H}$. Kopan), and he kept close in contact with him. He also in close contact with many prominent Ukrainian culture figures such as K. Stetsenko, O. Koshytz, V. Avramenko, M. Drimchenko, O. Oles.

Vasyl Yemetz's house was quite modest. A one-story bungalow. From the doorstep of the house one could see the cliff where the word HOLLYWOOD was erected in large white letters. In the corner of the living room was the bust of the blind kobzar I. KuchuhuraKucherenko that was sculpted by Vasyl's brother, Fedir, an artist who lived and worked in Berlin. He created the sculpture when he learned of the execution of the prominent kobzar ${ }^{1}$.

Memories are one thing, but those who are 40 years old can sometimes be incomplete. Many of these memories and observations were recovered with the help of the recordings ${ }^{2}$ that were made by myself at the time, and with the entries from the diary that I then kept, much comes back from oblivion.

${ }^{1}$ Ivan Kuchuhira-Kucherenko was a traditional blind kobzar who rose to the prominence of National artist of Ukraine. He was arrested in 1936 and executed in 1937 by the NKVD.

${ }^{2}$ Sections of these recordings areavailable on Youtube: https://www.youtube.com/watch?v=y82il8uBwT8 The diary has also been published http://www.infoukes.com/lists/banduraforum/ 
A young 18-year-old bandurist and collector of kobzar antiquities I had specific issues that were somewhat different from those that interest me today. What was considered important at that time seems to have lost pits importance today. At that time, I was interested in mastering bandura technique and how to refine and develop it. I was also interested in new and unique compositions and how to play the bandura in a manner that would capture the public. Today, these accents have shifted, and I am more interested in other aspects: the connection of modern players with the authentic blind kobzars, how these people lived, how they communicated, what works were retained in their repertoire and what aspects they paid more attention to at the time, as well as principles for the formation of early bandura playing technique.

Today I understand that there was a kobzar tradition that was considerably different from that which we hear in contemporary concert performance by concert bandurists. The requirements of the tradition were also different from those of a concert performer. The listening audience was also different, as the performance requirements were. Kobzar traditions were different from the modern culture of entertainment today. The kobzars usually did not have in their repertoire songs played solely for entertainment nor for the sake of applause. They sang songs, kants, psalms, and works of a mournful nature that had a particular social function that bordered on the sacred. Just like sacred works performed in church the audience did not applaud these renditions. It is inappropriate to applaud a song that songs about death, or misery. They received for their professional renditions or services a reward or honorarium instead of applause. Such music filled a psychological need to sound out about suffering, misery, injustice and unrighteousness and to have listeners share these feelings. Through their fulfillment, they united people to face misfortune and unrighteousness proving that they could jointly live through the misery that prevailed around.

It was the kobzar's repertoire that included songs about truth, falsehood and injustice. There are numerous songs that characterize the life of a Ukrainian peasant in those times, where aspects of everyday life were hidden by lies, and where history and truth were distorted.

For the young collector of kobzar materials, I was more interested in songs that had a more positive and uplifting effect on the public - entertaining pieces. These included humorous songs, and I noticed that the ancient humor of Eastern Ukrainians was somewhat unusual for a young man who grew up in Australia. Ukrainians are the kind of people who can cry and laugh at the same time, and often laughed through misery and injustice, and song has become a tool to help overcome misery. They ridiculed persons in rural life who deviated from standard behavior and social norms.

Yemetz had several concert instruments throughout his life. The first instrument he acquired in 1908 was the work of master bandura maker Anton Paplynsky in Kyiv. This instrument was tuned diatonically and had 32 strings -8 basses and 24 treble strings.

In 1912, Yemetz later ordered a new instrument from Paplynsky, a more sophisticated model. This instrument now had 12 basses and 22 treble strings but was also tuned diatonically through 4 and half octaves. This instrument became Yemetz's main concert instrument on which he played and toured all over Europe and North America. It was very light and quite fragile and had to be repaired numerous times, most notably the replacement of the soundboard. The treble strings had metal pegs, although the basses 
continued to have wooden tuning pegs. This bandura became the model for instruments that were made later in Czechoslovakia in the 1920's and in Galicia in the 1930's.

Later, when the Yemetz began to expand his concert repertoire, he had to chromaticize the bandura in some way. He began to develop experimental instruments to satisfy the growing demands of his repertoire, where he began to include transcription of classical music and had to tackle various problems in mastering the technique of playing on a chromatic bandura.

Yemetz made several experimental instruments, the last instrument being a large concert band with 62 strings tuned chromatically with a range of 5 full chromatically tuned octaves.

This instrument had a large soundboard, and although the shape of the instrument was somewhat cumbersome and inconvenient, it did give a fuller, louder and richer sound. There were no mechanical devices to rapidly retune the instrument. Chromatization was achieved by the addition of chromatic strings that were arranged in a specific manner: on the bridge, the strings were divided into two rows - the main row corresponding to the white keys on the piano and the auxiliary secondary lower row where the chromatic strings were arranged which corresponded to the black keys. On the edge of the instrument, all the strings were in the same plane, so that the strings on the instrument produced a chromatic row along the edge.

On such an instrument Yemetz could play his previous mastered concert repertoire with his right hand on the strings nearer the bridge, as before, and with the left he had easy access to the full chromatic row. When he played his right hand, he played usually near the bridge on the diatonic row and when he raised the hand towards the upper edge, he had easy access to all the additional chromatic sounds. The left hand in the normal position, that is, playing on the edge of the instrument had access to the chromatic row but when thrown over the edge of the instrument - he had access to the diatonically tuned row.

The basis of V. Yemetz's repertoire was primarily folk songs that were popular in the early twentieth century. In addition, he included some dumas, kants and psalms that were part of the traditional kobzar repertoire, as well as some instrumental dances. At this time, the parameters of stage bandura performance were being formulated - a concert performance of repertoire mostly for entertainment, which included urban romances, historical songs and humorous songs that were not normally found in the traditional kobzar repertoire, but whose function was to entertain the concert audience.

Yemetz's repertoire included works to the words of poets who formed contemporary Ukrainian consciousness, and also included newly created historical songs - songs that sang about the historical events of those times.

With each year Yemetz increased the number of instrumental compositions in his performances, as more and non-Ukrainian listeners came to his performances. In the beginning, these were folk dance tunes and marches, which were expanded in form and complexity throughthe use of variations. It also included medleys, and fantasies, built on then popular folk tunes. In order to expand these work's he performed different passages and parts using variations in technique: tremolo, tremolando, playing overtones, alternating the tempo and dynamics in order to distinguish the individual parts as much as possible and show the diverse technical capabilities not only of the instrument, but also of the artist. 
Purely instrumental compositions such as "Church Bells" and "The Dancing Snowflakes" began to emerge - where folk tunes were expanded by the artist's creative intent as much as possible.

Compositions began to appear that distinguished different ethnographic zones of Ukraine, using tunes that were popular in those regions with the poetic names "In the Steppes of Ukraine", "From the Crimean Mountains" and "In the Carpathian Mountains of Ukraine".

It should be noted that at one time Yemetz had few competitors in Ukraine regarding bandura playing, and there were no similar bandurists of his caliber in the Ukrainian Diaspora at all. He was the consummate virtuoso and one of those who pioneered the process of improving playing technique, and one can only wonder where he gathered ideas and inspiration to replenish his repertoire in such conditions where bandurists where there were no bandurists at all. We rarely see such enthusiastic and expanded creativity in the performance of bandura players today in Ukraine.

One can notice a parallel in approaches between Hnat Khotkevych and Vasyl Yemetz. This is seen in composition, playing technique and in shaping the phenomenon of "bandurism". Despite the fact that they were both born in the Sloboda region and knew about each other's existence - and had friends in common - they never actually met in person. At the time when Yemetz developed his concert activity, Khotkevych had emigrated to Western Ukraine, and when Khotkevych returned, Yemetz was living and studying in Moscow. When Yemetz returned to Kharkiv, Khotkevych was in exile, and when Khotkevych returned to Kharkiv, Yemetz was in Kyiv and then emigrated.

One of the mediators between Yemetz and Khotkevych was the traditional kobzar Ivan Kuchuhura Kucherenko, from whom Vasyl Yemetz initially learned to play the bandura. Kucherenko conveyed much of what he had learned from Khotkevych - to Yemetz such as the duma about of Khmelnytsky and the duma about the death of the Kozak bandurist, which were originally composed by Khotkevych, and learned orally from Kucherenko by Yemetz.

Most of the music manuscripts that V. Yemetz wrote out have been unfortunately lost. Almost all of Yemetz's musical compositions and arrangements, and a significant collection of archival transcription of authentic kobzar repertoire, which he recorded from such traditional kobzars as I. Kucherenko were destroyed. They were all stored in a traveling trunk, which during his Canadian tour was left in the basement of the house of prof. P. Matsenko in Winnipeg. At this time there was a large flood and the house was inundated and all the manuscripts were destroyed by water.

Some things however survived or were recreated, and Yemetz showed me a handful of music, some of which included published works in a collection from Prague in the mid 1920's. Unfortunately, we could not copy and take a picture of what he showed. I planned to return to copy everything in the next visit. Unfortunately, this did not happen.

Yemetz initially refused not only to play for me but he would not even take the bandura into his hands. After a few days, I was finally able to get him demonstrate me some exercises. The first I remember was his demonstration of playing arpeggios in a downward direction, that is, instead of playing the arpeggios from the lowest string to 
the highest, he did so in the reverse from the highest string to the lowest, whereby he could also change the accented note in the process of playing the arpeggio so that the accent would fall on different notes within the chord.

In tremolando playing, he not only played the chord like a series of upward arpeggios but also down and up and down. At the same time, he controlled the tempo of tremolando as a means of bringing out the particular phrase he was playing.

In his playing technique, Yemetz avoided using his first finger (thumb) and did not alternate it in the process of playing scales up or down, but used 2-3-4 fingers in different rotations in order to have control over the fluidity of notes of the scale. In many passages, he would drag his fingers along the strings as traditionally played by kobzars, and in more complex works, which required full control over each finger. He alternatively played with a pluck stroke followed by a rest stroked, and distinguished certain melodic figurations by the alternation of these articulations.

When playing the strings with his left hand, he pointed out that when playing along the side of the instrument the player should play as close to the centre of the string as possible to achieve a "sweeter" sound. Yemetz played with the left-handed along the side of the instrument using a rest stoke, where the finger after striking a string would rest on the neighboring string, however when he threw his left hand over the side of the instrument he used a pluck stoke, where the fingertip would not touch the neighboring strings. In this position he would also use his thumb.

I played for Yemetz on my bandura (Chernihiv concert bandura with retuning mechanisms). I also played a little on the Kharkiv bandura and in a manner that finally lured him into taking his instrument into his own hands and playing. Initially he just gave advice regarding the playing of specific exercises and techniques such as tremolo and tremolando. He tried several times to describe the process, and finally took the bandura in his hands and demonstrated his approach to these techniques.

We had a conversation about various exercises and the difficulties of their execution and what needed attention in order to develop and improve playing technique. One often does not understand technical aspects until the attention is brought to this specific element in technique. He especially focused his attention on tremolo, tremolando, some scallic passages paying the particular attention to the manner of holding the left hand on the bandura when it was thrown over the side of the instrument.

Yemetz did not use the terminology developed by modern academic bandura players at conservatories in Ukraine (Broiako, 1997). He used linguistic expressions and concepts, which were grounded in folk language.

We discussed repertoire. In his Jubilee album he had a list of all the songs and instrumental compositions that he had performed throughout his career. Turning on the tape recorder, I managed to record almost everything, lyrics and melodies particularly focusing on rare works, especially the melodies of those songs that the tradition kobzar Ivan Kucherenko sang which were sometimes somewhat unusual. Of the vocal works, perhaps the most valuable today were the melodies of traditional Ukrainian dumas that Yemetz sang, though I only managed to record them only partially and without bandura accompaniment. The most interesting of all the recording is probably the melody of the Duma about Khmelnytsky that Yemetz had learned from Ivan Kucherenko, which has not been recorded by anyone anywhere else. 
When we recorded all his songs, we later discussed his instrumental compositions, and although he did not play them on the bandura, he sang their melodies and described them how they sounded.

At one point he pulled out a signal copy of a long-playing record which he had prepared for replication, but which he had not published. On an ancient record player, he played the record and I managed to record parts of the recordings. On one side was the composition "From the Carpathian Mountains" - a work that was based on old Ukrainian motifs, including tunes to "Arkan". On the flip side were recordings of "Snow dance", "In the steppes of Ukraine" and some other dances. The record was instrumental and was intended for the non-Ukrainian audience. He had recorded it in 1955-58 years in Hollywood, but it was not released because he was dissatisfied with the quality of the recording. His wife intended to release the record after this death, but this did not happen as both died in 1982.

During my stay Vasyl Yemetz was preparing a book of memoirs about his concert tour through Transcarpathia in 1927, which at that time was part of Czechoslovakia writing about the problems he encountered during the tour, and his perception and understanding of the local population in the struggle against the influence of the Russian culture, which was undermining the Ukrainian cause in those years.

Yemetz was a calm soul, but his eyes would brighten up and become agitated when he started talking about the Cossack ideal and about the realm of Hetman Paul Skoropadsky. Yemetz considered himself a Ukrainian monarchist, and he was of conservative political opinion. Some of his views did not quite fit in with more widespread thinking of the Ukrainian post WWII Diaspora in the USA.

In Hollywood, there were few Ukrainians, and most were from Galicia in Western Ukraine and did not understand or appreciate the mentality of Ukrainians from Eastern Ukraine who left the Russian Empire during the revolution, and, in addition, did not fully appreciate the bandura which was considered a rather unusual musical instrument in the eyes of the Galician Diaspora - unpromising (i.e. it was not possible to make a living from playing it) particularly in normal American life.

He had some conflicting encounters with members of the Ukrainian community in Los Angeles. The new administration of the Ukrainian community praised historical figures that Yemetz personally knew and which did not gain his respect. He contributed a considerable share of the money to build a Ukrainian cultural center in Los Angeles, which a group of post WWII emigrants had taken over. He thought that he was ill-treated and was insulted by them and this had a negative effect on him and his future attendance at Ukrainian community functions.

There are reports that Yemetz played the bandura producing some background music to some Hollywood films. Apparently, the bandura was supposed to play Arabic music. Yemetz did not advertise this fact, and these films and the recordings have not been found.

In France, in the 1930s, Yemetz performed with singer Roksolana Verbytska (Vitvitska) accompanying her singing with his bandura playing. They toured France and Belgium with concerts featuring not only Ukrainian songs, but also songs in different languages. The French firm PATE issued recordings of their renditions. Newspaper reviews stated that these were the best recordings of Ukrainian music and songs that have ever made. 
Yemetz at the time apparently was going to marry this singer, but when he returned from touring Canada, she had married someone else. Yemetz was disillusioned. Since then her name was not mentioned anywhere, neither in his memoirs nor in his writings.

Vasyl Yemetz's brother Fedir, was an artist and sculptor and worked in Berlin. He had a son, Troyan, who at one time was a student at the Ukrainian high School in Salzburg, where my father had also studied. Yemetz's legacy, after his death and the death of his wife, passed into his hands, and I contacted him to purchase the recording, manuscripts and instruments. Unfortunately, this did not happen as the negotiations suddenly stopped.

One question that was difficult to understand was why no one in the Ukrainian Diaspora visited Yemetz and did not study with him after he settled in the North America. In California such prominent figures as V. Bozhyk and Hryhoriy Kytasty lived relatively close by, but no one visited him nor did anyone record any information. It is evident that he understood his place in Ukrainian music and wanted to pass on his experiences and creations through the correspondence he had with Nicholas Czorny at the NY Bandura School and with other prominent figures of Ukrainian culture in North America.

While studying with V. Yemetz I was able to observe the daily life of this outstanding artist who was at that time 89 years old. He would in his exercise regime walk around his house several times a day, and did a variety yoga exercises. One that left an impression was him was standing on his head for 15 minutes, so that his legs were raised straight up. He would be silent and focusing on something. He would go silent and breathed deeply in a specific manner. He could control his body completely. This is perhaps one of the secrets to his mastery regarding changes in tempo and dynamics and the fact that he could concentrate intensely on his performance that he never made mistakes when playing large and complex instrumental compositions.

\section{Conclusions}

Vasyl Yemetz was during his lifetime a unique individual and musician who made a significant impact on the development bandura technique, repertoire and also bandura construction. He stood at the crossroads from the traditional kobzar playing tradition to modern concert performance and repertoire.

Through the use of audio recordings and notes much information can still be reclaimed and reinterpreted through indirect study and review of source materials, particularly in areas such as bandura playing technique and repertoire. The development and introduction of specific terms to describe playing techniques can be applied to Yemetz's bandura playing technique. The recording of Yemetz singing the melodies of pieces from his repertoire are a fine starting point for the reconstruction of pieces from his repertoire.

The recordings and notes also shed light on the reasons why his made specific decisions regarding repertoire, playing technique and bandura construction. These decisions shed light onto the philosophy of Yemetz regarding the development and future direction of the bandura. 


\section{References}

Broiako, N. B. (1997). Teoretychni aspekty vykonavskoi tekhniky bandurysta [Theoretical aspects of performance techniques of bandurists] [Monograph]. Vasyl Stefanuk Precarpathian National University [in Ukrainian].

Diakowsky, M. J. (1958). The Bandura. The Ukrainian Trend, 1, 18-36 [in English].

Dutchak, V. H. (2011). Zberezhennia i rozvytok rehionalnykh tradytsii kobzarskoho instrumentariiu v ukrainskomu zarubizhzhi (kinets XX - pochatok XXI st.) [Preservation and development of regional traditions of kobza instruments in Ukrainian abroad (end of $X X$ - beginning of the XXI century)]. Ukrainska kultura: mynule, suchasne, shliakhy rozvytku, 17(1), 230-234 [in Ukrainian].

Mishalov, V. (2013). Kharkivska bandura: kulturolohichno-mystetski aspekty genezy i rozvytku vykonavstvo na ukrainskomu narodnomu instrumenti [The Kharkiv bandura: the genesis, development of a Ukrainian folk instrument]. Vydavets Savchuk O. O. [in Ukrainian].

Mizynec, V. (1987). Folk Instruments of Ukraine. Bayda Books [in English].

Samchuk, U. (1976). Zhyvi struny: bandura i bandurysty [Living strings: bandura and bandurists]. Vydannia Kapely bandurystiv imeni T. Shevchenka [in Ukrainian].

Yemetz, V. (1923). Kobza i kobzari [The kobza and kobzars]. Ukrainske Slovo [in Ukrainian].

Yemetz, V. (1961). U zolote 50-richchia na sluzhbi Ukrainy [To the golden 50 th anniversary in service of Ukraine]. Z drukarni O. O. Vasyliian [in Ukrainian].

\section{У БАНДУРНОМУ ВИКОНАВСТВІ ВАСИЛЯ ЄМЦЯ}

\section{Віктор Мішалов}

кандидат мистецтвознавства, науковий співробітник;

ORCID: 0000-0002-5194-8964; e-mail: victor.mishalow@yahoo.com

Університет Монаша, Мельбурн, Австралія

\section{Анотація}

У XX столітті окремі особистості в українській діаспорі зберігали, розвивали і пропагували кобзарські традиції та аспекти культури гри на бандурі, значна частина яких зникла в Україні внаслідок репресій.

Василь Ємець здійснив вагомий внесок у розвиток сучасного бандурного мистецтва та запропонував стандарт встановлення сольного концертного виконавства на інструменті. Запропоноване дослідження покликане зібрати та систематизувати нові джерела інформації про традиційні й новітні прийоми гри, які розробив В. Ємець, а також здійснити аналіз його репертуару на основі ремінісценцій та записів, зроблених автором у 1979 році.

Мета дослідження - проаналізувати та виявити трансформаційні та інноваційні процеси у виконавській техніці Василя Ємця; здійснити порівняльну характеристику традиційного та новаторського у творчості виконавця у контексті сучасного бандурного виконавства в Україні. 
Методологія дослідження ґрунтується на історичному, системному, соціологічному та культурному підходах. Застосовано методи наукового вивчення, зокрема, історикохронологічний аналіз методик гри на бандурі Василя Ємця; методи системної класифікації та комплексного аналізу ігрових прийомів, які він розробив. Метод аналізу спрямований на виконавську техніку гри та концертний репертуар Василя Ємця, його філософську інтерпретацію бачення ролі бандурного мистецтва у культурних процесах.

Джерельну базу дослідження включають: книги та статті про бандуру (головно, про Василя Ємця), особисті записи на касетах та фотографії, зроблені автором. Окремі висновки та узагальнення проведено на основі особистої взаємодії з митцем.

Наукова новизна дослідження полягає у введенні в науковий обіг органологічного та ергологічного аналізу мистецької діяльності бандуриста Василя Ємця. Вперше здійснено порівняльну характеристику традиційного та новаторського у творчості виконавця у контексті сучасного бандурного виконавства в Україні.

Висновки. Василь Ємець був унікальною людиною і музикантом. Він здійснив значний вплив на розвиток техніки гри на бандурі, репертуару та конструкції інструмента. Митець поєднав у своїй творчості традиційну кобзарську гру та новації сучасного концертного виконавства.

Аудіозаписи й фотоматеріали, здійснені під час особистих зустрічей, сприяли переосмисленню його мистецького, філософського, культурологічного доробку, особливо в аспектах технології виконавства і формування концертного матеріалу. Розроблені та впроваджені виконавцем музичні терміни для опису ігрових прийомів можна і сьогодні застосовувати у методиці бандурної гри. Аудіозаписи мелодій, здійснені під час інтерв'ю сприяли реконструкції його репертуару та активного залучення цих творів до концертного репертуару сучасних бандуристів.

Виокремлено взаємозв'язок технічних виконавських прийомів та конструктивних особливостей інструмента, що пояснює мотиви філософського осмислення ролі бандурного мистецтва у світовому культурному процесі.

Ключові слова: бандура; кобзар; Василь Ємець; техніка гри; українська діаспора

\section{ТРАДИЦИЯ И НОВАТОРСТВО В БАНДУРНОМ ИСПОЛНИТЕЛЬСТВЕ ВАСИЛИЯ ЕМЦА}

\section{Виктор Мишалов}

кандидат искусствоведения, научный сотрудник;

ORCID: 0000-0002-5194-8964; e-mail: victor.mishalow@yahoo.com

Университет Монаша, Мельбурн, Австралия

\section{Аннотация}

В XX веке отдельные личности в украинской диаспоре сохраняли, развивали и пропагандировали кобзарские традиции и аспекты культуры игры на бандуре, значительная часть которых исчезла в Украине в результате репрессий.

Василий Емец совершил весомый вклад в развитие современного бандурного искусства и предложил стандарт установки сольного концертного исполнительства 
на инструменте. Предложенное исследование призвано собрать и систематизировать новые источники информации о традиционных и новейших приемах игры, которые разработал В. Емец, а также произвести анализ его репертуара на основе реминисценций и записей, сделанных автором в 1979 году.

Цель исследования - проанализировать и выявить трансформационные и инновационные процессы в исполнительской технике Василия Емца; осуществить сравнительную характеристику традиционного и новаторского в творчестве исполнителя в контексте современного бандурного исполнительства в Украине.

Методология исследования основывается на историческом, системном, социологическом и культурном подходах. Применены методы научного изучения, в частности, историко-хронологический анализ методик игры на бандуре Василия Емца; методы системной классификации и комплексного анализа игровых приемов, которые он разработал. Метод анализа направлен на исполнительскую технику игры и концертный репертуар Василия Емца, его философскую интерпретацию видения роли бандурного искусства в культурных процессах.

Источниковую базу исследования включают: книги и статьи о бандуре (в основном, о Василии Емце), личные записи на кассетах и фотографии, сделанные автором. Отдельные выводы и обобщения проведены на основе личного взаимодействия с творцом.

Научная новизна исследования заключается во введении в научный оборот органологического и эргологического анализа художественной деятельности бандуриста Василия Емца. Впервые осуществлено сравнительную характеристику традиционного и новаторского в творчестве исполнителя в контексте современного бандурного исполнительства в Украине.

Выводы. Василий Емец был уникальным человеком и музыкантом. Он оказывал значительное влияние на развитие техники игры на бандуре, репертуара и конструкции инструмента. В. Емец соединил в своем творчестве традиционную кобзарскую игру и новации современного концертного исполнительства.

Аудиозаписи и фотоматериалы, сделанные во время личных встреч, способствовали переосмыслению его художественного, философского, культурологического наследия, особенно в аспектах технологии исполнительства и формирования концертного материала. Разработанные и внедренные исполнителем музыкальные термины для описания игровых приемов, можно и сегодня применять в методике бандурной игры. Аудиозаписи мелодий, совершенные во время интервью, способствовали реконструкции его репертуара и активного привлечения этих произведений в концертный репертуар современных бандуристов.

Выделена взаимосвязь технических исполнительских приемов и конструктивных особенностей инструмента, что объясняет мотивы философского осмысления роли бандурного искусства в мировом культурном процессе.

Ключевые слова: бандура; кобзарь; Василий Емец; техника игры; украинская диаспора 